\title{
EFFICIENCY OF TWO DIFFERENT ENTOMOPATHOGEN FUNGI BEAUVERIA BASSIANA AND PURPUREOCILLIUM LILACINUM TR1 AGAINST TETRANYCHUS URTICAE
}

\author{
YEŞILAYER, A. \\ Department of Plant Protection, Faculty of Agriculture, Gaziosmanpasa University, 60216 \\ Tokat, Turkey \\ (e-mail: ayse.yesilayer@gop.edu.tr; phone: +90-356-256-1616)
}

(Received 26 $6^{\text {th }}$ Jun 2018; accepted $31^{\text {st }}$ Aug 2018)

\begin{abstract}
Two-spotted red spider/red spider mite is an important pest of cultivated crops. Resistance is one of the most important problems in the intensive chemical control used in traditional management methods. Therefore, researchers have been using alternative control methods in pest management to overcome resistance problem. This study was conducted between 2015 and 2017 to investigate the effects of entomopathogenic fungi (EPF) Beauveria bassiana and Purpureocillium lilacinum TR1 on Tetranychus urticae (Koch) (Acarina: Tetranychidae). The doses used for P. lilacinum were $10^{4}, 10^{5}, 10^{6}$, $10^{7}, 10^{8}$ and $1.610^{8}$ conidia $\mathrm{ml}^{-1}$ and for B. bassiana $10^{4}, 10^{5}, 10^{6}, 10^{7}, 10^{8}, 10^{9}$ and $3.7 \times 10^{9}$ conidia $\mathrm{ml}^{-1}$. After five days the results showed that mortality of T. urticae adults were started with $10^{5}$ conidia $^{-1}$ concentration of B. bassiana and after seven days $10^{4}$ conidia $\mathrm{ml}^{-1}$ concentration of $P$. lilacinus. At the end of the trial, the mortality rate recorded by the highest doses, $10^{8}$ conidia/ml, of both EPFs were 28.3 and 66.6\% with P. Lilacinus and B. bassiana. Since many EPF fungi are thought to be epizootic, B. bassiana and $P$. lilacinum can be effectively used against $T$. urticae control as biological agents.
\end{abstract}

Keywords: two spotted spider mites, entomopathogenic fungi, control, Turkey

\section{Introduction}

The polyphagous pests are among the most harmful pest groups of agricultural products (Vacante, 2016). Tetranychus urticae is also an important pest of cultivated crops. Hatched two-spotted spider mites ((TSSM) mostly fed on the lower surface of leaves. The TSSM causes destruction in leaves by feeding in approximately 18-22 plant cells in a minute. After inserting the stylet like mouthparts into leaf cells, secretes the enzyme and absorbs the cell contents. Consequently, leaves are turned on pale, yellowish, gray or bronze-colored spots and causing drying and defoliation. In addition, adults cause damage by spinning tight and silk webs on the plants (Anonymous, 2008). Approximately 4000 different host plant species of $T$. urticae have been identified in worldwide (Migeon and Dorkeld, 2010, 2017) as well as in different studies conducted in Turkey (Yabaş and Ulubilir, 1995; Bulut, E., 1999; Yeşilayer, 2009).

The most preferred method in TSSM management is chemical control which is inexpensive and easy to adapt. However, one of the most important disadvantages of continuous use of chemical control is the resistance of $T$. urticae to the pesticides over time (Keena and Granett, 1987; Herron and Rophail, 1998; Van Leeuwen et al., 2004). New methods which can be alternative or complementary to chemical control of pests have recently been studied and especially importance of biological control is increasing as a suitable alternate method. Biological control is an appropriate method to sustainable agricultural techniques and sensible to human and animal health. The main components of this method used in pest control are parasitoids, predators and entomopathogens (K1lınçer et al., 2010; Dermauw et al., 2013). Studies conducted to date have reported approximately 500 fungi species as pathogenic in insects The 
entomopathogenic fungi species of Lagenidium, Entomophaga, Neozygites, Entomophytora, Erynia, Aschersonia, Lecanicillium, Nomuraea, Hirsutella, Metarhizium, Beauveria and Isaria have gained importance in the field of plant protection (Erkılıç and Uygun, 1993; Kılıç and Yıldırım, 2008). P. lilacinus is known as a nematophagus fungi and used to control mites and insects. In addition, EPN activity of entomopatogen fungus $B$. bassiana against $T$. urticae and insects has also been demostrated (Örtücü and Albayrak İskender, 2017).

Thee fungi do not develop resistance in mites, insects and like other pesticides, have absence of any toxic effects on ecology and have potential for future biotechnological developments. The longtime control, infecting the development period of their hosts, applicability with many insecticides and easiness in for mass production are also other advantages of these fungi (Demirbag, 2008). Fungi directly enter from the cell wall. The spores on cuticle settle here and germinate. The germinating spores enter due to the appressorium (penetration peg). The hyphae in epidermis and hypodermic grow, continue to proliferation in the insect body and blood cells and cause the death of insect (Ortiz-Urquiza, 2013). Commercial preparation of some entomopathogenic fungi as mycoinsecticides (B. bassiana, Metarhiz anisopliae, Hirsutell thompsoni) are available in the world and Turkey (Kilinçer et al., 2010). Recent studies have recorded the efficiency of some EPFs such as B. bassiana, Verticillium lecanii and M. anisoplia against two spotted spider mites (Chandler et al., 2005). The aim of this study was to evaluate the efficiency of two different entomopathogenic fungi, Purpureocillium lilacinum and Beauveria bassiana against Tetranychus urticae.

\section{Material and methods}

\section{Plant and mites culture}

Bean used as host plant Phaseolus vulgaris L. (Fabaceae) was grown in production cabinets at $25 \pm 2{ }^{\circ} \mathrm{C}, 65 \pm 5 \%$ relative humidity and $16 \mathrm{~h}$ lights: $8 \mathrm{~h}$ darkness photoperiod in the Plant Protection Department of Faculty of Agriculture, Gaziosmanpaşa University in Tokat-Turkey. The plants, at 5-6 leaves stage were transferred to the production cabin to be used in the production of two-spotted red spiders. Cultures of Tetranychus urticae were reared in climate chambers of Plant Protection Department, Faculty of Agriculture, Gaziosmanpasa University. The infected bean plant leaves with mites were cut and placed on non-infected plants to infect.

\section{Cultures of entomopathogenic fungus}

The EPFs used in the study, Purpureocillium lilacinum (syn: Paecilomyces lilacinus (Thom) Samson) TR1 and Beauveria bassiana (Balsamo) Vuillemin were obtained from the stock cultures of Prof. Dr İlker KEPENEKÇİ (Department of Plant Protection, Faculty of Agriculture, Gaziosmanpasa University) and from Prof. Dr. Fikret DEMIRCI (Department of Plant Protection, Faculty of Agriculture, Ankara University), respectively. The fungus was produced at the PDA medium to obtain sufficient spore suspension. Pure entomopathogenic isolates were planted using with glass hokey stick. After 4 weeks, $5 \mathrm{ml}$ of $0.02 \%$ Tween 80 solution was added to the petri dishes containing the cultures and homogenous mixing of fungi spores was achieved by spreading with glass hokey stick. The resulting suspension was then filtered through a sterile material to remove particulates, and transferred to $15 \mathrm{ml}$ and $50 \mathrm{ml}$ centrifuge 
tubes. The centrifuge tubes were shaken for $5 \mathrm{~min}$ on a Vortex shaker to separate the clustered fungi spores in the fungi suspensions. The spore intensity was determined using Thoma slide and light microscopy (Gabarty et al., 2014). Afterwards, each fungi isolate was diluted and the number of spores was adjusted.

\section{Bioassay}

Total of 13 different conidial concentrations were prepared to study the efficiency of entomopathogenic fungi on T. urticae. The conidial concentrations included 7 different doses of $B$. bassiana $\left(1 \times 10^{4}, 1 \times 10^{5}, 1 \times 10^{6}, 1 \times 10^{7}, 1 \times 10^{8}, 1 \times 10^{9}\right.$ and $3.7 \times 10^{9}$ conidia $\left.\mathrm{ml}^{-1}\right)$ and 6 different intensities of $P$. lilacinum $\left(1 \times 10^{4}, 1 \times 10^{5}, 1 \times 10^{6}, 1 \times 10^{7}, 1\right.$

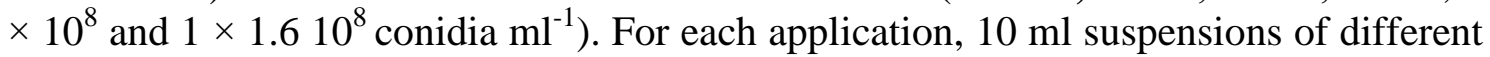
spore-density solutions were shaken for 2-3 min on the Vortex shaker. The EFPs, then, were sprayed to the leaves using a hand sprayer $(2.5 \mathrm{ml})$. For each application, $10 T$. urticae adults were used. Fungi solutions were sprayed to the down side of bean leaf disc and placed on a moist cotton in Petri dishes. Adult mites were transferred with a fine brush to the surface of leaf disc. Sterile distilled water $\left(\mathrm{dH}_{2} \mathrm{O}\right)$ containing $0.02 \%$ Tween 80 was sprayed onto the leaves in the control. Mortality values were counted on days 1, 3, 5, 7 and 9 after the application, and mycosis rates observed on days 7, 11 and 19 were recorded. Mites, mortality in mycosis experiment were placed on a moist filter paper in $9 \mathrm{~cm}$ sterile glass petri dishes and fungal development was observed.

Daily maintenance and humidity control were carried out during the experiments. The experiment was set up with three replicates and repeated twice.

\section{Statistical analyses}

Data was subjected to the one-way analysis of variance (One-Way ANOVA), and mean values were compared by Tukey's test at $\mathrm{P}=0.05$ significance level (SPSS, 2011).

\section{Results}

Total of 13 concentrations of two different entomopathogenic fungi were applied to the adults of $T$. urticae under the laboratory conditions. Mortality using single dose of $10^{5}$ started to occur on days 3 and 5 after applications of P. lilacinum and B. bassiana, respectively. Mortality of $T$. urticae adults among the application of other concentrations after the single dose experiment, were observed from day 5 at $10^{6}$ concentration of $P$. lilacinum. The mortality rate at $10^{6}, 10^{7}$ and $10^{8}$ conidia $\mathrm{ml}^{-1}$ doses on day 9 was $28.3 \%$ and the mortality rate at the highest concentration $\left(1 \times 1.610^{8}\right.$ conidia $\mathrm{ml}^{-1}$ ) on day 11 was $76.6 \%$. The mortality rates were linearly increased with increasing the doses and days (Table 1). The counting results in day 3 of P. lilacinum application in controlling the adult mites was not significantly different $(\mathrm{P}>0.05)$. The mortality rates counted on days 5,7 and 9 at $10^{7}$ conidia/ml dose were statistically significant $(\mathrm{P}<0.05)$ and the mortality rate ranged from 20 to $61.6 \%$ (Table 1$)$.

The deaths of two-spotted adult mites at the highest concentration $\left(3.7 \times 10^{9}\right.$ conidia $\mathrm{ml}^{-1}$ ) of B. bassiana, the second EPF used in the study, started on day 3 and mortality rate reached to $20 \%$. The mortality rate was recorded as $91 \%$ on the last day (Table 2).

The mortality rates on days $5(13.3 \%)$ and $7(16.6 \%)$ at $10^{7}$ and $10^{8}{\text { conidia } \mathrm{ml}^{-1}}^{-}$ concentrations of $B$. bassiana were statistically significant $(\mathrm{P}<0.05)$. In contrast to $B$. 
bassiana, the difference between mortality rates obtained with $P$. lilacinum starting from $10^{8}$ conidia $\mathrm{ml}^{-1}$ concentration on day 3 was significant $(\mathrm{P}<0.05)$. The differences between mortality rates on days 5 and 7 were similar, though statistically significant $(\mathrm{P}<0.05)$. Mortality has not been observed after 3 days treatment with $10^{4}$ but mortality was $48.3 \%$ at end of the day 9.

Table 1. Effect of P. lilacinum on T. urticae (\% mortality rate $\pm S E$ )

\begin{tabular}{c|c|c|c|c}
\hline Concentration $\left({\text { conidia } \mathbf{~ m l}^{\mathbf{1}} \text { ) }}^{\text {th }}\right.$ & $\mathbf{3}^{\text {th }}$ & $\mathbf{5}^{\text {th }}$ & $\mathbf{7}^{\text {th }}$ & $\mathbf{9}^{\text {th }}$ \\
\hline Control & $0.00 \pm 0.00 \mathrm{a}$ & $0.00 \pm 0.00 \mathrm{a}$ & $1.66 \pm 1.66 \mathrm{a}$ & $1.66 \pm 1.66 \mathrm{a}$ \\
$10^{4}$ & $0.00 \pm 0.00 \mathrm{a}$ & $0.00 \pm 0.00 \mathrm{a}$ & $10.00 \pm 0.00 \mathrm{a}$ & $20.00 \pm 0.00 \mathrm{a}$ \\
$10^{5}$ & $0.00 \pm 0.00 \mathrm{a}$ & $0.00 \pm 0.00 \mathrm{a}$ & $11.66 \pm 1.66 \mathrm{a}$ & $21.66 \pm 0.18 \mathrm{a}$ \\
$10^{6}$ & $0.00 \pm 0.00 \mathrm{a}$ & $1.66 \pm 2.43 \mathrm{a}$ & $11.66 \pm 1.66 \mathrm{a}$ & $28.33 \pm 1.23 \mathrm{a}$ \\
$10^{7}$ & $0.00 \pm 0.00 \mathrm{a}$ & $3.33 \pm 2.10 \mathrm{~b}$ & $15.00 \pm 2.23 \mathrm{ab}$ & $28.33 \pm 1.23 \mathrm{a}$ \\
$10^{8}$ & $0.00 \pm 0.00 \mathrm{a}$ & $10.00 \pm 1.56 \mathrm{~b}$ & $20.00 \pm 1.45 \mathrm{~b}$ & $28.33 \pm 1.23 \mathrm{a}$ \\
$1 \times 1.610^{8}$ & $0.00 \pm 0.00 \mathrm{a}$ & $28.33 \pm 1.33 \mathrm{c}$ & $38.33 \pm 1.66 \mathrm{c}$ & $61.66 \pm 2.32 \mathrm{~b}$ \\
\hline
\end{tabular}

Means followed in the same column by different letters are significantly different $\mathrm{P}<0.05$, Tukey test

Table 2. Effects of B. bassiana on T. urticae adults (\% mortality rate $\pm S E$ )

\begin{tabular}{c|c|c|c|c}
\hline${\text { Concentration }\left(\mathbf{c o n i d i a ~} \mathbf{~ m l}^{\mathbf{1}}\right)}^{\text {) }}$ & $\mathbf{3}^{\text {th }}$ & $\mathbf{5}^{\text {th }}$ & $\mathbf{7}^{\text {th }}$ & $\mathbf{9}^{\text {th }}$ \\
\hline Control & $1.66 \pm 1.66 \mathrm{a}$ & $1.66 \pm 1.66 \mathrm{a}$ & $1.66 \pm 1.66 \mathrm{a}$ & $13.33 \pm 2.10 \mathrm{a}$ \\
$10^{4}$ & $0.00 \pm 0.00 \mathrm{a}$ & $1.66 \pm 2.43 \mathrm{a}$ & $1.66 \pm 2.43 \mathrm{a}$ & $48.33 \pm 12.75 \mathrm{abc}$ \\
$10^{5}$ & $0.00 \pm 0.00 \mathrm{a}$ & $8.33 \pm 3.01 \mathrm{ab}$ & $8.33 \pm 3.01 \mathrm{ab}$ & $31.66 \pm 2.56 \mathrm{a}$ \\
$10^{6}$ & $0.00 \pm 0.00 \mathrm{a}$ & $11.66 \pm 1.66 \mathrm{ab}$ & $11.66 \pm 1.66 \mathrm{ab}$ & $41.66 \pm 3.06 \mathrm{ab}$ \\
$10^{7}$ & $0.00 \pm 0.00 \mathrm{a}$ & $13.33 \pm 2.10 \mathrm{ab}$ & $13.33 \pm 2.10 \mathrm{ab}$ & $58.33 \pm 2.86 \mathrm{bc}$ \\
$10^{8}$ & $10.00 \pm 0.00 \mathrm{~b}$ & $16.66 \pm 2.10 \mathrm{~b}$ & $16.66 \pm 2.10 \mathrm{~b}$ & $66.66 \pm 2.10 \mathrm{~cd}$ \\
$10^{9}$ & $16.66 \pm 2.10 \mathrm{c}$ & $45.00 \pm 6.70 \mathrm{c}$ & $45.00 \pm 6.70 \mathrm{c}$ & $88.33 \pm 3.42 \mathrm{de}$ \\
$3.7 \times 10^{9}$ & $20.00 \pm 2.58 \mathrm{c}$ & $45.00 \pm 2.23 \mathrm{c}$ & $45.00 \pm 2.23 \mathrm{c}$ & $91.38 \pm 0.45 \mathrm{e}$ \\
\hline
\end{tabular}

Means followed in the same column by different letters are significantly different $\mathrm{P}<0.05$, Tukey test

\section{Mycosis study with EPF fungus}

Mycosis observations were conducted on days 7, 11 and 19 within the efficiency study against $T$. urticae adults included the different concentrations of the two EPF fungi. The mycosis rate on the end of day 7 at the lowest concentration $\left(10^{4}{\text { conidia } \mathrm{ml}^{-}}^{-}\right.$ ${ }^{1}$ ) was $10 \%$ and it was $51.6 \%$ at the end of the 19 th day. The mycosis development rates of six different $P$. lilacinum concentrations on various days showed mycosis development on day 7 at $1 \times 10^{5}, 1 \times 10^{6}$ and $1 \times 10^{7}$ conidia/ml concentrations, but the difference was not statistically significant $(\mathrm{P}>0.05)$. The rate of mycosis development at $1 \times 10^{8}$ and $1 \times 1.610^{8}$ conidia $\mathrm{ml}^{-1}$ concentrations on day 7 was statistically significant $(\mathrm{P}<0.05)($ Table 3$)$.

Similar to $P$. lilacinum ( $P$. lilacinus), the mycosis development rates conducted at different concentrations of $B$. bassiana started to be observed from the day 7 . The mycosis development rate at the highest concentrations of $1 \times 10^{7}, 1 \times 10^{8}$ and $1 \times 1.6$ $10^{8}$ conidia $\mathrm{ml}^{-1}$ ranged from 20 to $45 \%$ and it was statistically significant $(\mathrm{P}<0.05)$. The rate of mycosis development, which increased to over $50 \%$ at the highest 
concentrations from the day 11, linearly increased. The minimum mycosis development rate at $10^{4}$ conidia $\mathrm{ml}^{-1}$ concentration on the end of day 19 which was the last day was $58.3 \%$. The mycosis development rate at $1 \times 10^{8}, 1 \times 10^{9}$ and $3.7 \times 10^{9}$ conidia ml $^{-1}$ concentrations was $100 \%$ and the difference was statistically significant $(\mathrm{P}<0.05)$ (Table 4).

Table 3. P. lilacinus of mycosis rate (\%)

\begin{tabular}{c|c|c|c}
\hline Concentration $\left(\right.$ conidia $\left.^{\mathbf{- 1}}\right)$ & $\mathbf{7}^{\text {th }}$ & $\mathbf{1 1}^{\text {th }}$ & $\mathbf{1 9}^{\text {th }}$ \\
\hline Control & $0.00 \pm 0.00 \mathrm{a}$ & $0.00 \pm 0.00 \mathrm{a}$ & $0.00 \pm 0.00 \mathrm{a}$ \\
$1 \times 10^{4}$ & $10.00 \pm 0.00 \mathrm{a}$ & $21.66 \pm 1.66 \mathrm{~b}$ & $51.66 \pm 3.45 \mathrm{~b}$ \\
$1 \times 10^{5}$ & $13.33 \pm 2.10 \mathrm{~b}$ & $28.33 \pm 1.66 \mathrm{~b}$ & $65.00 \pm 2.23 \mathrm{c}$ \\
$1 \times 10^{6}$ & $13.33 \pm 2.10 \mathrm{~b}$ & $38.33 \pm 1.66 \mathrm{c}$ & $81.66 \pm 3.07 \mathrm{~d}$ \\
$1 \times 10^{7}$ & $20.00 \pm 2.52 \mathrm{~b}$ & $45.00 \pm 2.23 \mathrm{c}$ & $100.00 \pm 0.00 \mathrm{e}$ \\
$1 \times 10^{8}$ & $31.66 \pm 1.66 \mathrm{c}$ & $55.00 \pm 3.42 \mathrm{~d}$ & $100.00 \pm 0.00 \mathrm{e}$ \\
$1 \times 1.610^{8}$ & $45.00 \pm 5.00 \mathrm{~d}$ & $60.00 \pm 2.58 \mathrm{~d}$ & $100.00 \pm 0.00 \mathrm{e}$ \\
\hline
\end{tabular}

Means followed in the same column by different letters are significantly different $\mathrm{P}<0.05$, Tukey test)

Table 4. B. bassiana of mycosis rate (\%)

\begin{tabular}{c|c|c|c}
\hline Concentration $\left({\left.\mathbf{c o n i d i a ~} \mathbf{~ m l}^{\mathbf{1}}\right)}^{\text {) }}\right.$ & $\mathbf{7}^{\text {th }}$ & $\mathbf{1 1}^{\text {th }}$ & $\mathbf{1 9}^{\text {th }}$ \\
\hline Control & $0.00 \pm 0.00 \mathrm{a}$ & $0.00 \pm 0.00 \mathrm{a}$ & $0.00 \pm 0.00 \mathrm{a}$ \\
$1 \times 10^{4}$ & $11.66 \pm 1.66 \mathrm{~b}$ & $28.33 \pm 1.66 \mathrm{~b}$ & $58.33 \pm 3.66 \mathrm{~b}$ \\
$1 \times 10^{5}$ & $15.00 \pm 2.23 \mathrm{~b}$ & $40.00 \pm 2.06 \mathrm{c}$ & $71.66 \pm 1.66 \mathrm{c}$ \\
$1 \times 10^{6}$ & $16.66 \pm 2.10 \mathrm{~b}$ & $43.33 \pm 2.10 \mathrm{c}$ & $81.66 \pm 1.66 \mathrm{~d}$ \\
$1 \times 10^{7}$ & $21.66 \pm 1.66 \mathrm{~b}$ & $53.33 \pm 3.21 \mathrm{~d}$ & $86.66 \pm 2.10 \mathrm{~d}$ \\
$1 \times 10^{8}$ & $36.66 \pm 2.10 \mathrm{c}$ & $66.66 \pm 2.10 \mathrm{e}$ & $100.00 \pm 0.00 \mathrm{e}$ \\
$1 \times 10^{9}$ & $50.00 \pm 4.47 \mathrm{~d}$ & $78.33 \pm 3.44 \mathrm{f}$ & $100.00 \pm 0.00 \mathrm{e}$ \\
$3.7 \times 10^{9}$ & $70.00 \pm 3.16 \mathrm{e}$ & $78.00 \pm 3.00 \mathrm{f}$ & $100.00 \pm 0.00 \mathrm{e}$ \\
\hline
\end{tabular}

Means followed in the same column by different letters are significantly different $\mathrm{P}<0.05$, Tukey test

The difference between observed mycosis rates of both EPF applications was statistically significant $(\mathrm{P}<0.05)$. The mycosis development rate at the lowest concentration on the day 11 varied from 21 to $60 \%$ for $P$. lilacinum and from 28 to $78 \%$ for $B$. bassiana. The mycosis development rates of two different EPFs at different concentrations on days 7, 11 and 19 are presented in Figure 1a-d.

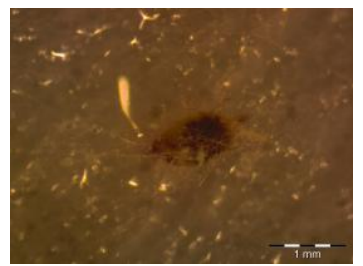

a

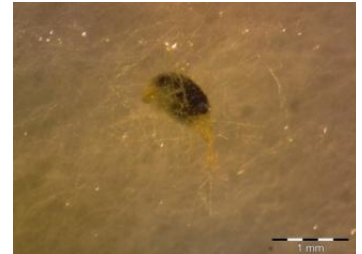

b

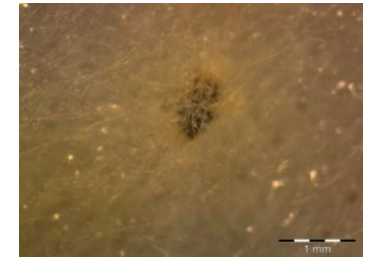

c

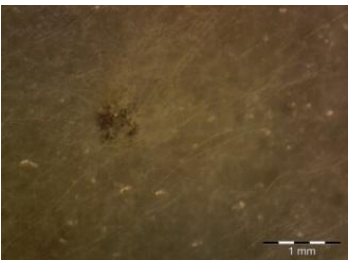

d

Figure 1. The mycosis development rates a- P. lilacinus $10^{5}, b$ - P. lilacnius $10^{7}, c$ - B. bassiana $10^{5}, d$ - B. bassiana $10^{7}$ micosis 
The mycosis rates at $10^{4}$ conidia $\mathrm{ml}^{-1}$ concentration of B. bassiana and P. lilacinum were recorded on days 7,11 and 19 . The mycosis development at $10^{4}$ conidia $\mathrm{ml}^{-1}$ concentration in both fungi application was similar at the end of day 19 day. The lowest mycosis rates at $10^{4}$ conidia $\mathrm{ml}^{-1}$ concentration on day 7 were 13.3 and $15 \%$ for $P$. lilacinum and $B$. bassiana, respectively. The mycosis rate on day 19 was lower in $P$. lilacinum than in $B$. bassiana. The lowest mycosis rates at $10^{6}$ conidia $\mathrm{ml}^{-1}$ concentration on day 7 were 13.3 and $16 \%$ for $P$. lilacinum and B. bassiana, respectively. The mycosis rate of $P$. lilacinum from day 11 at $10^{7}{\text { conidia } \mathrm{ml}^{-1}}^{1}$ concentration was $45 \%$ while that of $B$. bassiana was over $50 \%$. The mycosis rate at the highest common concentration $\left(10^{8}\right.$ conidia $\left.\mathrm{ml}^{-1}\right)$ on day 11 was recorded over $50 \%$ for both fungi while a mycosis rate of $100 \%$ was recorded on day 19 .

\section{Discussion}

The lowest mortality rate for both fungi, $P$. lilacinum and $B$. bassiana, used in the study at the lowest concentration of $10^{4}$ conidia $\mathrm{ml}^{-1}$ on day 9 was $20 \%$ and $48.3 \%$, respectively. The mortality rate at the highest concentration on day 5 was found to be $28.3 \%$ for P. lilacinum and $45 \%$ for B. bassiana. The mortality and mycosis rates in the $B$. bassiana treatment were higher than that of $P$. lilacinum and the mortality rate of $T$. urticae at 7 different concentrations ranged from 10 to $100 \%$ between days 3 and 9 . Similarly, Shi et al. (2008b) reported that B. bassiana application caused 31.9 to $87.7 \%$ mortalities of Tetranychus cinnabarinus, a red spider, in a study with three different EPFs. In laboratory conditions, application of two different isolates of $B$. bassiana caused mortality between 22.1 and 82.6 of adult females of $T$. evansi mites (Wekesa et al., 2005). In another study conducted with four different EPFs, M. anisopliae V275 and $M$. anisopliae led to quite high mortality on adult stages of $T$. urticae. In the same study, M. flavoviride, L. lecanii and B. bassiana were found effective in the adult stage by $57.8,50$ and $45.8 \%$, respectively, and the differences in adult mortality rates caused by entomopathogenic fungi were statistically significant (Doğan, 2016). Shi and Feng (2009) and Wekesa et al. (2006) reported that entomopathogenic fungus applications resulted in deaths in $T$. urticae mites and also reduced their reproductive potentials. Tamai et al. (2002) investigated the effects of 45 isolates belonging to Aschersonia aleyrodis (1), Beauveria bassiana (32), Metarhizium anisopliae (10), Hirsutella sp. (1) and Paecilomyces farinosus on $T$. urticae. The concentration of entomopathogenic fungi

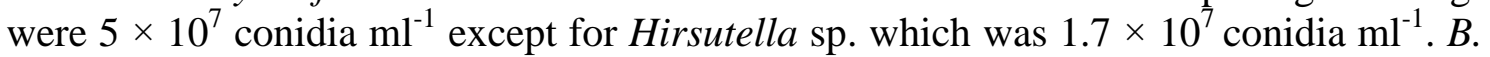
bassiana, Hirsutella sp. and M. anisopliae were found more pathogenic than other fungi used in the study, and these fungi have been reported causing mortalities of mites from the third day after inoculation. Similar to the findings of others, the mortality of mites in this study started after the third day of $10^{8}$ and $10^{9}$ conidia $\mathrm{ml}^{-1} . B$. bassiana application.

The highest mortality rate of $B$. bassiana at $1 \times 10^{7}$ conidia $\mathrm{ml}^{-1}$ concentration in this study was $58.3 \%$, while Dogan et al. (2017) reported $80 \%$ mortality on $T$. urticae at $1 \times$ $10^{7}$ concentration of the same fungus. Wu et al. (2016) reported 37 to $49 \%$ adult mortality at $1 \times 10^{7}$ concentration of different $B$. bassiana strains, and fungal virulence was attributed not only to strains but also to the concentration, frequency of application and formulation. Therefore, $80 \%$ mortality was reported from $T$. evansi and $T$. cinnabarinus strains of B. bassiana (Wekasa et al., 2005; Shi et al., 2008a). Bugeme et al. (2014) found that $1 \times 10^{7}$ conidia $\mathrm{ml}^{-1}$ concentration of $B$. bassiana and $M$. 
anisopliae increased the mortality rates of $T$. urticae nymphs and adults and both EPFs were found effective.

The $P$. lilacinum, in the experiment, was very effective in two-spotted spider mites. The mortality rate linearly increased with the increase in concentrations. The mortality

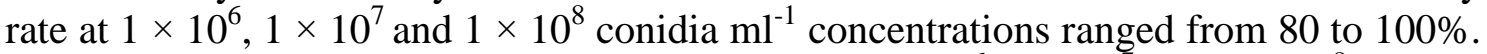
Amjad et al. (2012) applied three different doses $\left(1 \times 10^{6}, 1 \times 10^{7}\right.$ and $1 \times 10^{8}$ conidia $\mathrm{ml}^{-1}$ ) of Metarhizium anisopliae, Paecilomycis fumosoroseus (Wize) and Verticillium lecanii against $T$. urticae and reported $90 \%$ mortality with $P$. fumoroseus application. In this experiment, the mortality rate at $1 \times 1.610^{8}$ conidia $\mathrm{ml}^{-1} P$. lilacinum application was \%66.3. In addition, development of mycosis was observed on day 7 of P. lilacinum applications against mites tested. Amjad et al. (2012) have also observed mycosis development on adult female mites from day 7 of $P$. lilacinus application against Tetranychus kanzawai.

The results of efficacy study conducted in Tokat province of Turkey revealed that $B$. bassiana and $P$. lilacinum, entomopathogenic fungi, caused effective mortality of mites at the end of $72 \mathrm{~h}$ ( 3 days) and $120 \mathrm{~h}$ (5 days), respectively. The development of mycosis has been intense from the day 7 at both fungi application. The B. bassiana, comparing the mortality and mycosis rates, was more effective against red spider mites than P. lilacinum.

In conclusion, we may conclude from the laboratory results that $B$. bassiana and $P$. lilacinus can be successfully used in controlling T. urticae. However, greenhouse and field trials are needed to support the findings of this study and to obtain more effective control against $T$. urticae. The use of entomopathogens in management of two-spotted red spiders has more advantageous to practice in terms of human, environment, benefices and predators. In addition, mass production, formulation development, licensing and further research efforts are required on entomopathogens fungi.

Acknowledgements. The authors thank Prof. Dr. İlker Kepenekci (Gaziosmanpaşa University, Turkey) and B. bassiana Prof. Dr Fikret Demirci (Ankara University, Turkey) for providing P. lilacinum. This study was funded by Research Foundation (BAP-2015-137) of Gaziosmanpaşa University

\section{REFERENCES}

[1] Amjad, M., Bashir, M. H., Afzal, M., Sabri, M. A., Javed, N. (2012): Synergistic effects of some entomopathogenic fungi and synthetic pesticides, against two spotted spider mite, Tetranychus urticae Koch (Acarina: Tetranychidae). - Pakistan Journal of Zoology 44(4): 977-984.

[2] Anonymous (2008): Zirai Mücadele Teknik Talimatları. - T. C. Tarım ve Köyişleri Bakanlığı Koruma ve Kontrol Genel Müdürlüğü 3,183-268-276, 332 ss.

[3] Bugeme, D. M., Knapp, M., Boga, H. I., Ekesi, S., Maniania, N. K. (2014): Susceptibility of developmental stages of Tetranychus urticae (Acari: Tetranychidae) to infection by Beauveria bassiana and Metarhizium anisopliae (Hypocreales: Clavicipitaceae). International Journal of Tropic. Insect Science 34: 190-196.

[4] Bulut, E. (1999): Antalya ve Çevresinde sebze seralarında bulunan zararlılar ve doğal düşmanlarının saptanması. - Akdeniz Üniversitesi, Bitki Koruma Anabilim Dalı, Antalya.

[5] Chandler, D., Davidson, G., Jacobson, R. J. (2005): Laboratory and glasshouse evaluation of entomopathogenic fungi against the two-spotted spider mite, Tetranychus urticae 
(Acari: Tetranychidae), on tomato, Lycopersicon esculentum. - Biocontrol Science Techonology 15: 37-54.

[6] Demirbağ, Z. (2008): Entomopatojenler ve biyolojik mücadele. - Esen Ofset Matbaac1lık, Istanbul.

[7] Dermauw, W., Wybouw, N., Rombauts, S., Menten, B., Vontas, J., Grbic, M. (2013): A link between host plant adaptation and pesticide resistance in the polyphagous spider mite Tetranychus urticae. - Proceedings of the National Academy of Sciences of the USA 110: E113-E122.

[8] Doğan, Ö. Y. (2016): Entomopatpjen fungusların Tetranychus urticae'ye karş1 etkinliklerinin belirlenmesi. - Yüksek lisans tezi. Fen Bilimleri Enstitüsü, Adnan Menderes Üniversitesi.

[9] Doğan, Ö. Y., Hazır, S., Yıldız, A., Butt, T. M., Çakmak, İ. (2017): Evaluation of entomopathogenic fungi for the control of Tetranychus urticae (Acari: Tetranychidae) and the effect of Metarhizium brunneum on the predatory mites (Acari: Phytoseiidae). Biological Control 111: 6-12.

[10] Erkılıç, L., Uygun, N. (1993): Entomopatojen fungusların biyolojik mücadelede kullanılma olanakları. - Türkiye Entomoloji Dergisi 17(2): 117-128.

[11] Gabarty, A., Salem, H. M., Fouda, M. A., Abas, A. A., Ibrahim, A. A. (2014): Pathogencity induced by the entomopathogenic fungi Beauveria bassiana and Metarhizium anisopliae in Agrotis ipsilon (Hufn.). - Journal of Radiation Research and Applied Sciences 7: 95-100.

[12] Herron, G. A., J., Rophail, J. (1998): Tebufenpyrad $\left(\right.$ pyranica $^{(\mathrm{R})}$ ) resistance detected in two-spotted spider mite Tetranychus urticae Koch (Acarina: Tetranychidae) from Apples in Western Australia. - Experimental and Applied Acorology 22: 633-641.

[13] Keena, M, A., Granett, J. (1987): Cyhexatin and propargite resistance in populations of spider mites (Acari: Tetranychidae) from california almonds. - Journal of Economic Entomology 80: 560-564.

[14] K1lıç, E., Yıldırım, E. (2008): Beyazsineklerin (Homoptera: Aleyrodidae) mücadelesinde entomopatojen fungusların kullanım imkanları. - Atatürk Üniversitesi Ziraat Fakültesi Dergisi 39(2): 249-254.

[15] Kilınçer, N., Yiğit, A., Kazak, C., Er, M. K., Kurtuluş, A., Uygun, N. (2010): Teoriden Pratiğe Zararlılarla Biyolojik Mücadele. - Türkiye Bioloji Mücadele Dergisi 1: 15-59.

[16] Migeon, A., Dorkeld, F. (2016): Spider Mites Web: a Comprehensive Database for the Tetranychidae. - http://www.montpellier.inra.fr/CBGP/spmweb. Accessed 3 July 2017.

[17] Migeon, A., Nouguier, E., Dorkeld, F. (2010): Trends in Acarology. Spider Mites Web: A Comprehensive Database for the Tetranychidae. - Springer, Amsterdam, pp. 557-560.

[18] Ortiz-Urquiza, A., Keyhani, N. (2013): Action on the surface: entomopathogenic fungi versus the insect cuticle. - Insects 4(3): 357-374.

[19] Örtücü, S., Albayrak, N. (2017): Determination of control potentials and enzyme activities of Beauveria bassiana (Bals.) Vull. isolates against Tetranychus urticae Koch (Acari: Tetranychidae). - Trakya University Journal of Natural Sciences 18(1): 33-38.

[20] Shi, W. B., Feng, M. G. (2009): Effect of fungal infection on reproductive potential and survival time of Tetranychus urticae (Acari: Tetranychidae). - Experimental and Applied Acarology 48: 229-237.

[21] Shi, W. B., Zhang, L. L., Feng, M. G. (2008a): Field trials of four formulations of Beauveria bassiana and Metarhizium anisopliae for control of cotton spider mites (Acari: Tetranychidae) in the Tarim Basin of China. - Biological Control 45: 48-55.

[22] Shi, W. B., Zhang, L. L., Feng, M. G. (2008b): Time-concentration-mortality responses of Carmine spider mite (Acari: Tetranychidae) females to three hypocrealean fungi as biocontrol agents. - Biological Control 46: 495-501.

[23] Tamai, M. A., Alves, S. B., Almedia, J. E. M., de Faion, M. (2002): Evaluation of entomopathogenic fungi for control of Tetranychus urticae koch (Acari: Tetranychidae). 
- Centro de Pesquisa e Desenvolvimento de Sanidad Vegetal, Inst. Biology, Campinas, SP, Brasil.

[24] Vacante, V. (2016): The Handbook of Mites of Economic Plants. - CABI Publishing, Wallingford.

[25] Van Leeuwen, Stillatus, T., Tirry, L. (2004): Genetic analysis and cross-resistance spectrum of a laboratory-selected chlorfenapyr resistant of two spotted spider mite (Acari: Tetranychidae). - Experimental and Applied Acarology 32: 249-261.

[26] Wan, H. (2003): Molecular biology of the entomopathogenic fungus beauveria bassiana: insect-cuticle degrading enzymes and development of a new selection marker for fungal transformation. - Unpublished $\mathrm{Ph}$. D. Thesis, Combined Faculties for the Natural Sciences and for Mathematics of the Ruperto-Carola University of Heidelberg, Germany.

[27] Wekesa, V. W., Maniania, N. K., Knapp, M., Boga, H. I. (2005): Pathogenicity of Beauveria bassiana and Metarhizium anisopliae to the tobacco spider mite Tetranychus evansi. - Experimental and Applied Acarology 36(1-2): 41-50.

[28] Wekesa, V. W., Knapp, M., Maniania, N. K., Boga, H. I. (2006): Effects of Beauveria bassiana and Metarhizium anisopliae on mortality, fecundity and egg fertility of Tetranychus evansi. - Journal of Applied Entomology 130: 155-159.

[29] Wu, S., Xie, H., Li, M., Xu, X., Lei, Z. (2016): Highly virulent Beauveria bassiana strains against the two-spotted spider mite, Tetranychus urticae, show no pathogenicity against five phytoseiid mite species. - Experimental and Applied Acarology 435.

[30] Yabaş, C., Ulubilir, A. (1995): Akdeniz Bölgesi’nde biberde yeni saptanan bir zararlı Polyphagotarsonemus latus (Banks) (Acarina, Tarsonemidae). - Türkiye Entomoloji Dergisi 19(1): 43-46.

[31] Yeşilayer, A. (2009): İstanbul ili yeşil alanlarında zararlı akar (acarina) türlerinin tanımı, yayılışı, önemli türün populasyon yoğunluğu ve doğal düşmanları üzerinde araştırmalar. Ankara Üniversitesi Fen Bilimleri Enstitüsü Doktora Tezi.

\section{APPENDIX}

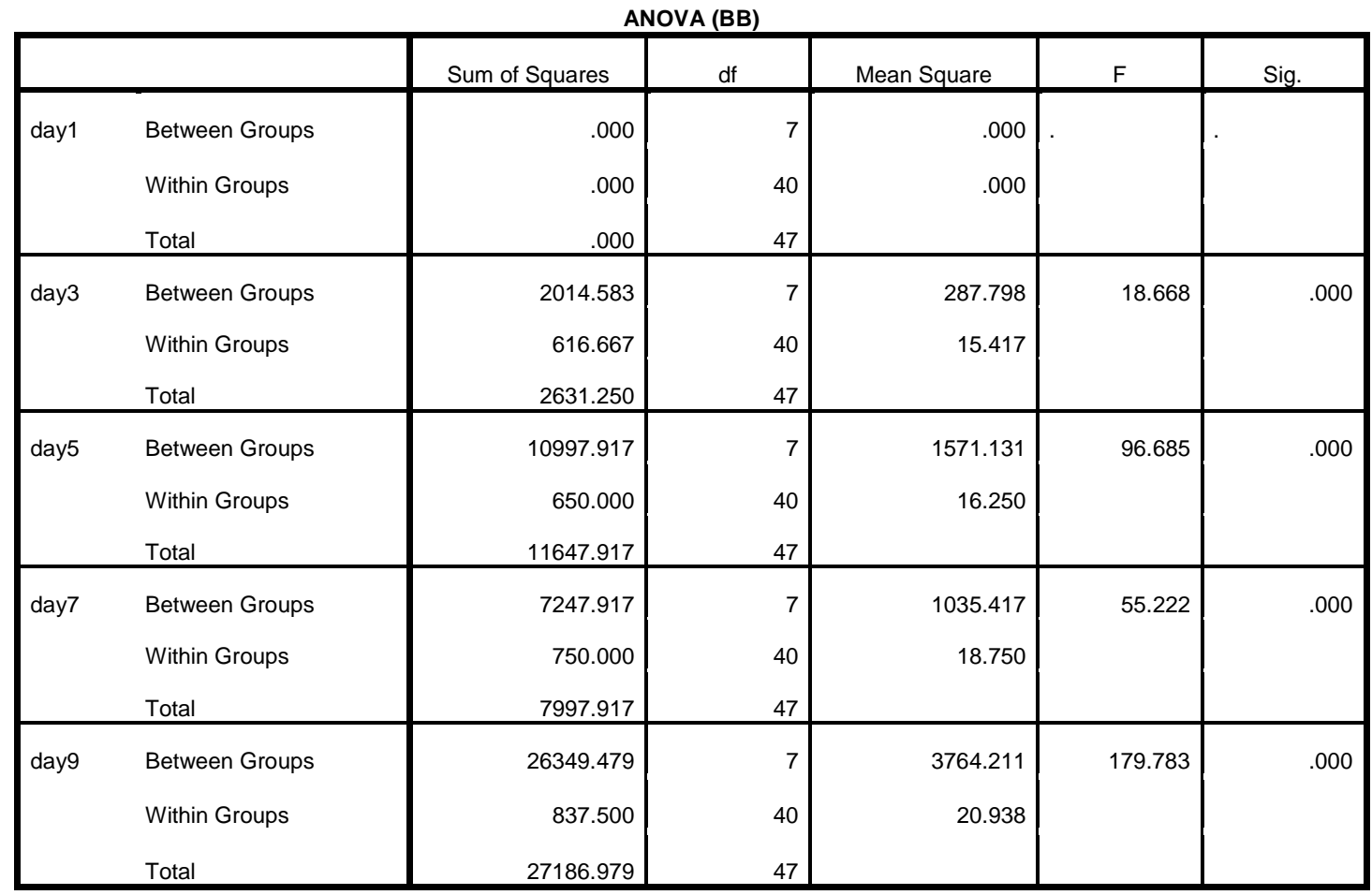




\begin{tabular}{|c|c|c|c|c|c|c|}
\hline \multicolumn{7}{|c|}{ ANOVA (PTR) } \\
\hline & & Sum of Squares & df & Mean Square & $\mathrm{F}$ & Sig. \\
\hline day1 & $\begin{array}{l}\text { Between Groups } \\
\text { Within Groups } \\
\text { Total }\end{array}$ & $\begin{array}{l}.000 \\
.000 \\
.000 \\
\end{array}$ & $\begin{array}{r}6 \\
35 \\
41 \\
\end{array}$ & $\begin{array}{l}.000 \\
.000\end{array}$ & & \\
\hline day3 & $\begin{array}{l}\text { Between Groups } \\
\text { Within Groups } \\
\text { Total }\end{array}$ & $\begin{array}{r}61.905 \\
416.667 \\
478.571 \\
\end{array}$ & $\begin{array}{r}6 \\
35 \\
41 \\
\end{array}$ & $\begin{array}{l}10.317 \\
11.905\end{array}$ & .867 & .529 \\
\hline day5 & $\begin{array}{l}\text { Between Groups } \\
\text { Within Groups } \\
\text { Total }\end{array}$ & $\begin{array}{r}3661.905 \\
500.000 \\
4161.905 \\
\end{array}$ & $\begin{array}{r}6 \\
35 \\
41 \\
\end{array}$ & $\begin{array}{r}610.317 \\
14.286\end{array}$ & 42.722 & .000 \\
\hline day7 & $\begin{array}{l}\text { Between Groups } \\
\text { Within Groups } \\
\text { Total }\end{array}$ & $\begin{array}{r}3447.619 \\
600.000 \\
4047.619 \\
\end{array}$ & $\begin{array}{r}6 \\
35 \\
41 \\
\end{array}$ & $\begin{array}{r}574,603 \\
17,143\end{array}$ & 33,519 & .000 \\
\hline day9 & $\begin{array}{l}\text { Between Groups } \\
\text { Within Groups } \\
\text { Total }\end{array}$ & $\begin{array}{r}7223.810 \\
766.667 \\
7990.476 \\
\end{array}$ & $\begin{array}{r}6 \\
35 \\
41\end{array}$ & $\begin{array}{r}1203.968 \\
21.905\end{array}$ & 54.964 & .000 \\
\hline
\end{tabular}

